\title{
Use of low-molecular-weight heparin in severe paraquat poisoning: a case report
}

Maria A. Montoya-Giraldo ${ }^{10}$, Luisa F. Díaz , Ubier E. Gómez ${ }^{1}$, Juliana Quintero² and Andres F. Zuluaga ${ }^{*}$ (i)

\begin{abstract}
Background: Acute paraquat ingestion remains a leading cause of mortality in developing countries. There is currently no evidence that treatment with high-dose immunosuppressants and antioxidants improves survival in patients with paraquat poisoning, and better options are urgently needed. Here, we describe the unexpected survival and recovery of a patient with a potentially fatal paraquat poisoning.

Case presentation: After ingesting $28 \mathrm{~mL}$ of paraquat ( $20 \%$ ion $\mathrm{w} / \mathrm{v}$ ), confirmed by a deep blue color in the urine dithionite test (UDT), a 17-year-old Hispanic Colombian boy was treated according to the hospital protocol with cyclophosphamide, methylprednisolone, N-acetylcysteine, vitamin E and propranolol. Gastrointestinal endoscopy showed extensive ulceration and necrosis. As a novelty, enoxaparin at a single dose of $60 \mathrm{mg}$ was added to his treatment. Despite the evidence of severe mucosal burns in the gastrointestinal tract and high paraquat concentrations found in the UDT, the clinical condition began to improve after 1 day of treatment, with full recovery and discharge from hospital after 21 days.

Conclusions: Although the amount of paraquat ingested by the patient was large and the UDT indicated severe poisoning with a somber prognosis, unexpected survival of the patient was observed, and the addition of enoxaparin was the only change from the standard treatment.
\end{abstract}

Keywords: Paraquat, Toxicity, Poisoning, Enoxaparin

\section{Introduction}

Paraquat (PQ) self-ingestion remains a leading cause of pesticide-induced mortality [1]. In Colombia, the burden of PQ intoxication between 2010 and 2016 was higher than that reported for all other chemicals, reaching 53.4 disability-adjusted life years (DALY) per 100,000 inhabitants [2].

Besides the accurate characterization of the patient's exposure, quantification of the plasma PQ concentration has remarkable value for assessing the prognosis [3]. Although liquid chromatographic methods are the gold

\footnotetext{
*Correspondence: andres.zuluaga@udea.edu.co

${ }^{1}$ CIEMTO [Drug and Poison Research and Information Center], Calle 64 \# 51-31, Laboratorio Integrado de Medicina Especializada (LIME), IPS

Universitaria, Facultad de Medicina, Universidad de Antioquia, Medellín, Antioquia, Colombia

Full list of author information is available at the end of the article
}

standard, their availability in emergency rooms is limited [4]. For this reason, a reliable and suitable rapid test such as the semiquantitative urine dithionite test (UDT) is preferred [3]. While the cutoff value for UDT is $2 \mathrm{mg} / \mathrm{L}$, a deep blue color correlates with plasma concentrations $>10 \mathrm{mg} / \mathrm{L}$ and $100 \%$ early lethality [3-5]. Patients usually receive high-dose immunosuppressants combined with antioxidants, but there is no evidence that this treatment improves survival in severe PQ poisoning [6, 7], and better therapeutic options are urgently needed. Thrombotic microangiopathy was recently elucidated as the primary systemic pathological event in PQ poisoning [8], but antithrombotic drugs have never been tested. Here, we describe the unexpected survival of a patient with severe PQ poisoning after adding enoxaparin to his treatment.

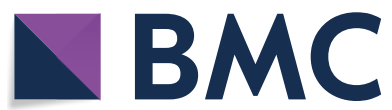

(c) The Author(s) 2020. Open Access This article is licensed under a Creative Commons Attribution 4.0 International License, which permits use, sharing, adaptation, distribution and reproduction in any medium or format, as long as you give appropriate credit to the original author(s) and the source, provide a link to the Creative Commons licence, and indicate if changes were made. The images or other third party material in this article are included in the article's Creative Commons licence, unless indicated otherwise in a credit line to the material. If material is not included in the article's Creative Commons licence and your intended use is not permitted by statutory regulation or exceeds the permitted use, you will need to obtain permission directly from the copyright holder. To view a copy of this licence, visit http://creativecommons.org/licenses/by/4.0/. The Creative Commons Public Domain Dedication waiver (http://creativeco mmons.org/publicdomain/zero/1.0/) applies to the data made available in this article, unless otherwise stated in a credit line to the data. 


\section{Case presentation}

A 17-year-old Hispanic Colombian boy from a rural area, troubled by familial and financial issues, tried to kill himself by allegedly consuming $28 \mathrm{~mL}$ of PQ (Gramoxone SL $1 \mathrm{~L}, 200 \mathrm{~g} / \mathrm{L}$ ion PQ), equivalent to a high dose of approximately $80 \mathrm{mg} / \mathrm{kg}$ of PQ ion [9]. Shortly after the ingestion he experienced a repulsive taste, severe odynophagia, dysphagia, stomach pain and vomiting. He was given kitchen oil and panela by his mother. Two hours had already passed when the patient arrived at the emergency department of a local hospital. Gastric lavage was done with activated charcoal. The patient also received vitamin $\mathrm{E}$ and $\mathrm{N}$-acetyl cysteine (NAC). He was then referred to the Hospital San Vicente Foundation (Medellin, Colombia) for further management.

On arrival 9 hours post-ingestion, the patient had arterial pressure of $123 / 65 \mathrm{mmHg}$, pulse rate of 78 per minute, respiratory rate of 16 per minute and $100 \%$ oxygen saturation. The following treatment was ordered: NAC $1.8 \mathrm{~g}$ in $500 \mathrm{~mL}$ of $5 \%$ dextrose to infuse over 1 hour, vitamin E $400 \mathrm{mg}$ orally every 12 hours, propranolol $40 \mathrm{mg}$ orally every 8 hours, methylprednisolone $1 \mathrm{~g}$ intravenously every 24 hours, cyclophosphamide $900 \mathrm{mg}$ in $500 \mathrm{~mL}$ of $5 \%$ dextrose to be infused over 1 hour, and omeprazole $40 \mathrm{mg}$ intravenously every 12 hours. Laboratory tests showed a white blood cell count of $11,750 / \mathrm{mm}^{3}$ ( $80 \%$ neutrophils), hemoglobin $16.6 \mathrm{~g} / \mathrm{dL}$ and hematocrit $50 \%$, platelets $428,000 / \mathrm{mm}^{3}$, prothrombin time 7 seconds, and activated partial thromboplastin time of 42 seconds. Electrocardiogram, liver enzyme and kidney function tests were normal. UDT showed a dark blue color at 12 hours post-ingestion (Fig. 1). Considering the large amount of PQ ingested, the positive UDT and the unavailability of hemoperfusion, the family was informed of the patient's poor prognosis. Based on reports of thrombotic microangiopathy as the primary systemic pathological event in $\mathrm{PQ}$ poisoning, a single dose of enoxaparin (60 mg subcutaneously) as an extraordinary measure was offered, to which the patient consented. As severe gastroesophageal chemical burns were found by endoscopy 84 hours post-ingestion (Fig. 2), the oral route was stopped for a week. There were no signs or symptoms of pulmonary compromise during the hospital stay, but thoracic high-resolution computerized tomography showed minimal and unspecific atelectatic changes. A second endoscopy at day 14 after PQ ingestion was normal, showing no residual stenosis, and the patient was discharged in good condition at day 21 . The patient was doing well at his 1-month health follow-up appointment.

\section{Discussion}

Here we report the unexpected survival and full recovery of a patient with severe $P Q$ poisoning after adding enoxaparin to the standard treatment.

Some factors may have had a positive role in the surprising survival of the patient: the unknown true amount of PQ ingested, receiving basic detoxification measures within a couple of hours, young age and good baseline health. However, PQ intoxication commonly affects healthy Colombian men ranging in age from 15 to 44 years [2], and it is well accepted that the ingestion of $>40$ $\mathrm{mg}$ PQ ion/kg of body weight results in early death (2448 hours) from multiple organ failure, independently of the treatment used $[6,7]$. Moreover, with a highly positive UDT (dark blue color) after 12 hours or more, the extensive gastrointestinal damage observed by endoscopy suggests that the absorption of PQ was almost complete, and detoxification measures were insufficient to explain the weakness of clinical presentation. Similar cases are frequently treated in our institution [10], but the prognosis in almost all cases correlates well with UDT level. Since 1979, it has been accepted that a plasma PQ concentration higher than $1 \mathrm{mg} / \mathrm{L}$ at 12 hours after poisoning correlates with mortality of at least $80 \%$ [11, 12]. In 1987, Scherrmann et al. evaluated the correlation between urine and plasma PQ concentrations [5], demonstrating that a dark blue color in UDT correlates with fatal plasma concentrations higher than $10 \mathrm{mg} / \mathrm{L}$ [13]. The lack of a confirmatory method such as gas chromatography was probably a limitation of our study, but it is accepted that a false-positive result in the urine dithionite test is unlikely, although there are cross-reactions with bilirubin at high levels [3]. In fact, it is possible to use this colorimetric method to distinguish between bipyridyl compounds: diquat (green color) and PQ (blue color) [14].

It is commonly accepted that PQ exerts injurious effects through oxidative stress and mitochondrial dysfunction [15], but as therapy with antioxidants and immunosuppressants has failed in clinical trials [6], other therapeutic options are needed. Although enoxaparin cannot be deemed directly responsible for the favorable evolution, recent experimental data support its biological plausibility, which deserves to be discussed in depth.

Pulmonary capillary endothelial cells are the direct targets of PQ toxicity after ingestion [16-18]. Recent studies have shown the role of the platelet endothelial cell adhesion molecule-1 (PECAM-1 or cluster of differentiation 31 [CD31]) in PQ poisoning. PECAM-1, a key member of the immunoglobulin superfamily adhesion protein, is a specific regulator of the endothelial junctional integrity [19] regulating vascular permeability and leukocyte exudation. Interestingly, PECAM-1 was found to be markedly reduced in $\mathrm{PQ}$ poisoning during acute 

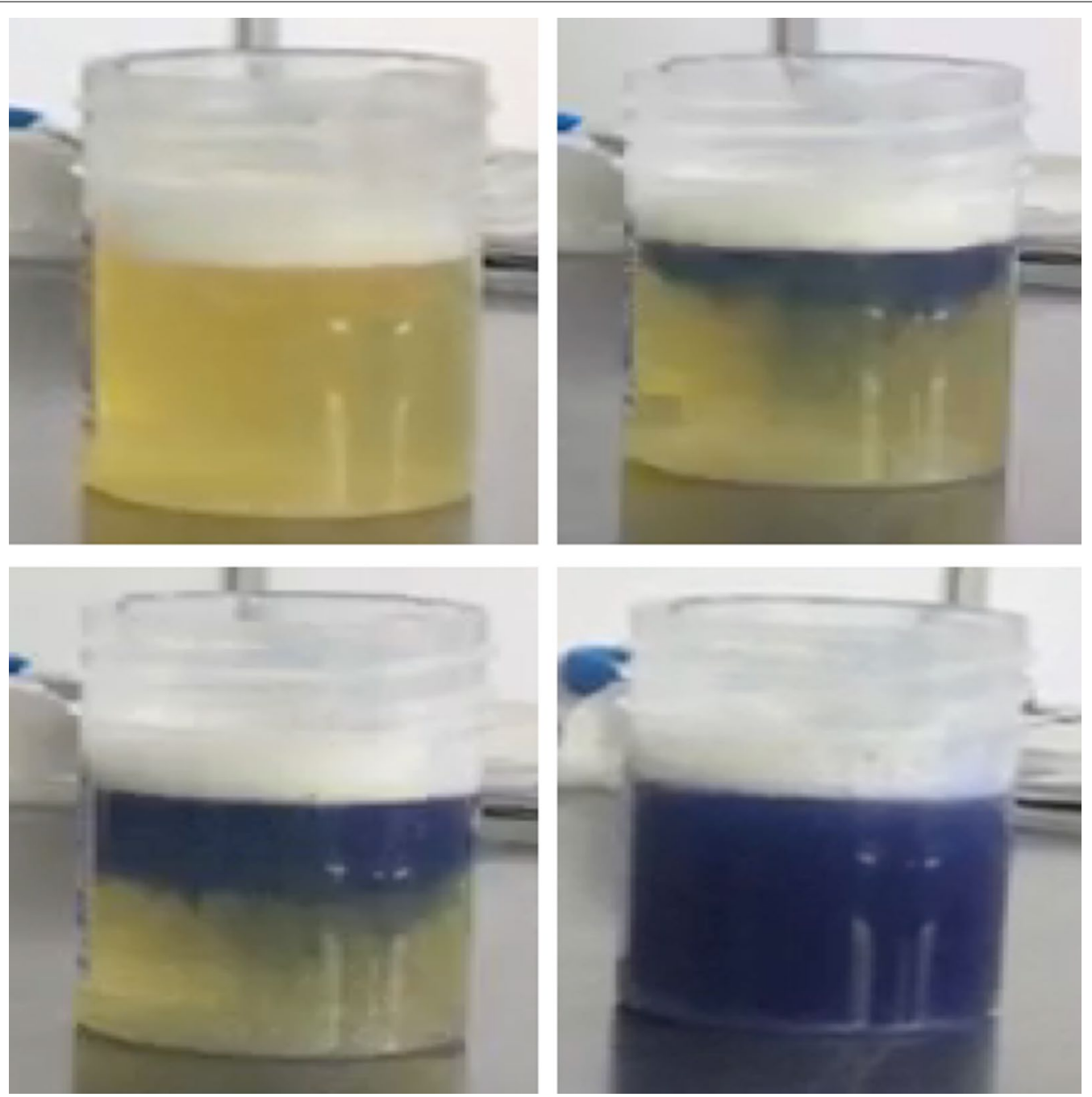

Fig. 1 The qualitative dithionite test in urine revealed a deep blue color

lung inflammation in rabbits [20]. Heparin and related drugs have been shown to bind the extracellular domain of PECAM-1 and also heparan sulfate on cell surfaces under conditions of mild acidosis [21, 22]. If the amelioration of the endothelial injury is due to the enoxaparin binding with PECAM-1, hampering its binding to PQ is a hypothesis that deserves to be tested in the future.

It is increasingly recognized that low-molecular-weight heparins (LMWH) have many pharmacological properties beyond their anticoagulant activity [21] [23]. As a naturally occurring molecule, endogenous heparin is specifically localized to immune mast cells in humans to physiologically modulate certain inflammatory pathways [24], for example through inhibition of the complement cascade. The complement system is a pivotal component of the innate immune system in the response against microorganisms, and it is dysregulated by toxic agents such as PQ [25]. Complement can be activated by three distinct pathways: the classical, alternative and lectin pathways. The specific heparin-complement protein interactions include inhibition of $\mathrm{C} 1 \mathrm{q}$ (initiator of the classical complement pathway), augmentation of factor $\mathrm{H}$ (soluble inhibitor of the alternative pathway) and inhibition of the lytic terminal complement complex [24]. The three pathways converge at the cleavage and activation of $\mathrm{C} 3$, generating split products with biological effector functions ( $\mathrm{C} 3$ opsonins, cytolytic membrane attack complex, and so on). In 2011, Sun demonstrated the key role of the complement factor $\mathrm{H}(\mathrm{CFH})$ in paraquat-induced acute lung injury in $\mathrm{PQ}$ poisoning in mice $[25,26]$. As LMWH have the strongest polyanionic negative charge known, binding to $\mathrm{CFH}$ is expected $[23,27,28]$. If the 

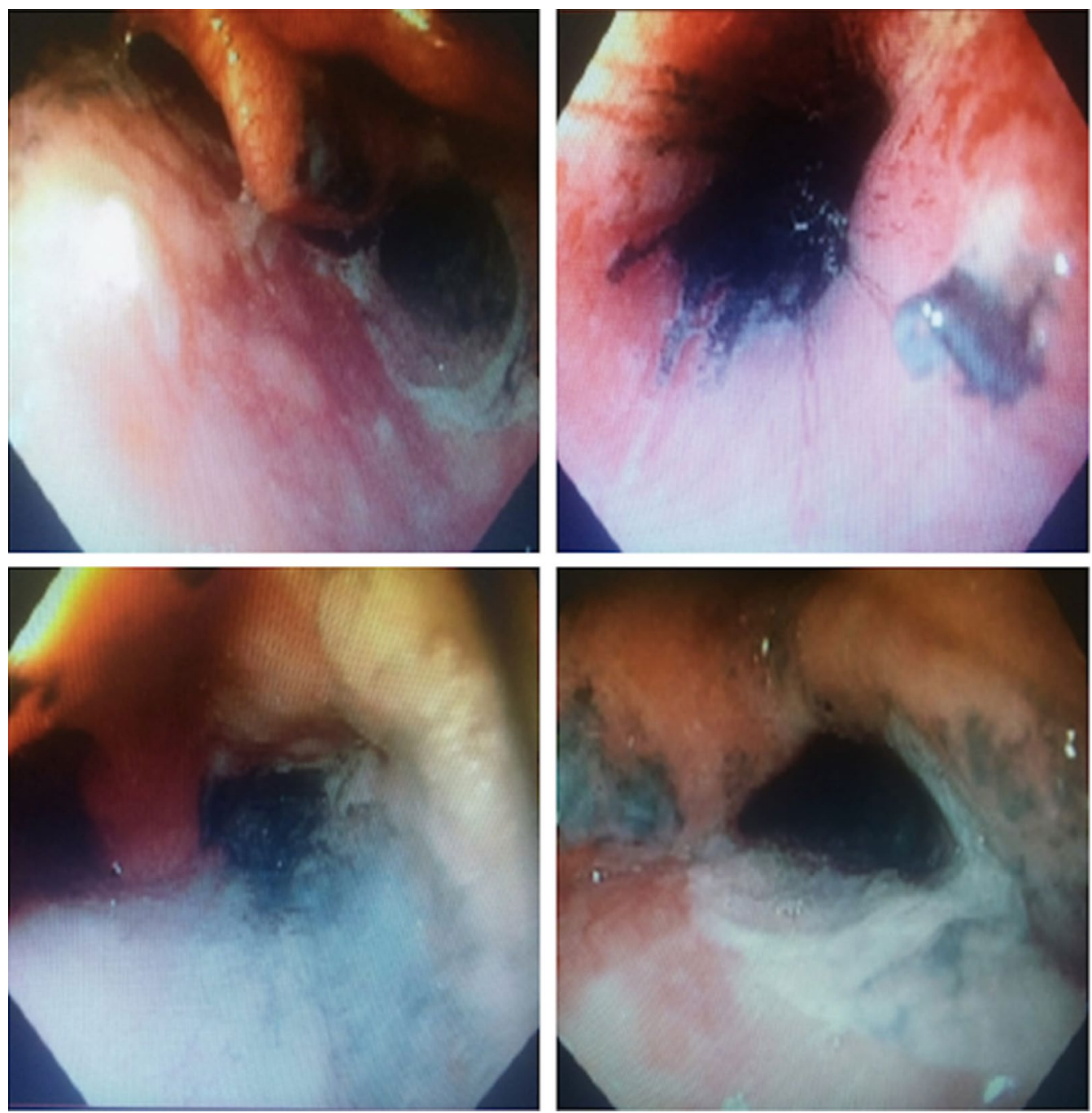

Fig. 2 Endoscopy of upper digestive tract. Supraglottic cricopharyngeal and mucosal structures of the middle third of the esophagus, with extensive and multiple ulcers covered with fibrin and hematin, with some areas of necrotic appearance

LMWH-CFH complex is a damage-limiting mechanism, downregulation of the alternative pathway in PQ poisoning is another hypothesis that deserves further testing $[29,30]$.

Remarkably, endothelial cell injury and thrombus formation in the microvascular environment in humans is called thrombotic microangiopathy (TMA), and druginduced TMA is complement-mediated [31]. Daisley et al. recently reported the histological examination of lungs from the autopsy of a PQ-poisoned patient [8]. The main finding was that pulmonary thrombotic microangiopathy was the primary pathological event in PQ poisoning, characterized by alveolar capillary thrombosis, atelectatic changes, destruction of alveolar walls, rupture of subpleural alveolar walls and emphysematous changes
[8]. Therefore, the potential for antithrombotic drugs in severe cases deserves to be tested [32].

Here, we chose enoxaparin for specific reasons. First, enoxaparin has more predictable pharmacokinetics than unfractionated heparin (UFH), and it has been used extensively in intensive care units, requiring a subcutaneous daily dose of $60 \mathrm{mg}$ [16]. Second, the hemopurification strategy for acute $\mathrm{PQ}$ poisoning in adults involves the use of enoxaparin [17]. Third, this drug has been tested in an animal model to prevent lung fibrosis induced by PQ [18].

Finally, regarding the dose, a daily dose of $40 \mathrm{mg}$ of enoxaparin has been used in pregnant women with a history of thromboembolic events during previous pregnancies, reducing the complement activity in vivo [19], but 
other anticoagulants (such as fondaparinux and hirudin) do not inhibit the generation of complement split products [20]. Moreover, Robinson et al. compared the effective dosage of enoxaparin for intensive care patients in 72 patients randomized in four groups to receive 40, 50, 60 or $70 \mathrm{mg}$ subcutaneously for a period of 24 hours, measuring the anti-factor $\mathrm{Xa}(\mathrm{aFXa})$ as evidence of antithrombotic activity, which demonstrated a ceiling effect at $60 \mathrm{mg}$ in a single dose [21].

\section{Conclusion}

Although the ingested amount of paraquat by the patient was large and the UDT indicated severe poisoning with a somber prognosis, unexpected survival of the patient was observed, and the addition of enoxaparin was the only change from the standard treatment. As there are many methodological flaws and confounders in this case report, more and better data are required to corroborate our observation.

\section{Acknowledgements}

We thank our colleague Carlos A. Rodriguez for the language editing.

\section{Authors' contributions}

MAM-G and AFZ participated in the case management and the conception of the report. All authors participated in the acquisition of additional information, interpretation of the results, writing of the text, and revision of the document. All authors read and approved the final manuscript.

\section{Funding}

No funding was received for this work.

\section{Availability of data and materials}

All data generated or analyzed during this study are included in this article.

\section{Ethics approval and consent to participate}

For this report, the CARE guidelines were adopted, and it was approved by the ethics committee of the Hospital San Vicente Fundacion.

\section{Consent for publication}

Written informed consent was obtained from the patient's legal guardian(s). A copy of the written consent is available for review by the Editor-in-Chief of this journal.

\section{Competing interests}

AFZ has received honoraria for unrelated lectures from AbbVie, Allergan, Amgen, Celltrion, Janssen, Lilly, Merck, Novartis, Novo Nordisk, Pfizer, Roche and Sanofi. MAMG has received honoraria for unrelated lectures from Novartis and Amgen. JQ, UG and LFD have no conflicts of interest.

\section{Author details}

${ }^{1}$ CIEMTO [Drug and Poison Research and Information Center], Calle 64 \# 51-31, Laboratorio Integrado de Medicina Especializada (LIME), IPS Universitaria, Facultad de Medicina, Universidad de Antioquia, Medellín, Antioquia, Colombia. ${ }^{2}$ Hospital Universitario San Vicente Fundación, Medellín, Colombia.

Received: 12 December 2019 Accepted: 28 October 2020

Published online: 08 December 2020

\section{References}

1. Gunnell D, Eddleston M, Phillips MR, Konradsen F. The global distribution of fatal pesticide self-poisoning: systematic review. BMC Public Health. 2007;7:357.

2. Buendia JA, Chavarriaga GJR, Zuluaga AF. Burden of paraquat poisoning in the department of Antioquia, Colombia. BMC Pharmacol Toxicol. 2019;20(1):11.

3. Koo JR, Yoon JW, Han SJ, Choi MJ, Park II, Lee YK, et al. Rapid analysis of plasma paraquat using sodium dithionite as a predictor of outcome in acute paraquat poisoning. Am J Med Sci. 2009;338(5):373-7.

4. Braithwaite RA. Emergency analysis of paraquat in biological fluids. Hum Toxicol. 1987;6(1):83-6.

5. Scherrmann JM, Houze P, Bismuth C, Bourdon R. Prognostic value of plasma and urine paraquat concentration. Hum Toxicol. 1987;6(1):91-3.

6. Gawarammana I, Buckley NA, Mohamed F, Naser K, Jeganathan K, Ariyananada PL, et al. High-dose immunosuppression to prevent death after paraquat self-poisoning - a randomised controlled trial. Clin Toxicol (Phila). 2018;56(7):633-9.

7. Gawarammana IB, Buckley NA. Medical management of paraquat ingestion. Br J Clin Pharmacol. 2011;72(5):745-57.

8. Daisley H, Rampersad A, Acco O, Meyers D. Paraquat poisoning and the lung pathology; vascular injury leading to thrombotic microangiopathy is the primary pathological event. J Lung Pulm Respir Res. 2018;5(6):164-6.

9. Barrueto F, Lee C, Pajoumand M, Yeung SY, Starr PE. Use of sirolimus in a case of severe paraquat poisoning. Clin Toxicol. 2008;46(8):778-9.

10. Zuluaga AF, Rodriguez CA, Lastra-Bello S, Pena-Acevedo LM, MontoyaGiraldo MA. CIEMTO: the new drug and poison research and information center in Medellin, Colombia. Clin Toxicol (Phila). 2017;55(7):684-5.

11. Proudfoot AT, Stewart MS, Levitt T, Widdop B. Paraquat poisoning: significance of plasma-paraquat concentrations. Lancet. 1979;2(8138):330-2.

12. Hart TB, Nevitt A, Whitehead A. A new statistical approach to the prognostic significance of plasma paraquat concentrations. Lancet. 1984;2(8413):1222-3.

13. Dinis-Oliveira R, Duarte J, Sánchez Navarro A, Remião F, Bastos ML, Carvalho F. Paraquat poisonings: mechanisms of lung toxicity, clinical features, and treatment. Crit Rev Toxicol. 2008:38:13-71.

14. Vohra R, Salazar A, Cantrell FL, Fernando R, Clark RF. The poison pen: bedside diagnosis of urinary diquat. J Med Toxicol. 2010;6(1):35-6.

15. Castello PR, Drechsel DA, Patel M. Mitochondria are a major source of paraquat-induced reactive oxygen species production in the brain. J Biol Chem. 2007;282(19):14186-93.

16. Zhang Q, Wu WZ, Lu YQ, Wang JZ, Shang AD, Yao F, et al. Successful treatment of patients with paraquat intoxication: three case reports and review of the literature. J Zhejiang Univ Sci B. 2012;13(5):413-8.

17. Cui JW, XuY, Wang Y, Gao YX, Guo S, Wang M, et al. Efficacy of initial haemopurification strategy for acute paraquat poisoning in adults: study protocol for a randomised controlled trial (HeSAPP). BMJ Open. 2018;8(6):e021964.

18. Buendia JA, Justinico Castro JA, Vela LJT, Sinisterra D, Sanchez Villamil JP, Zuluaga Salazar AF. Comparison of four pharmacological strategies aimed to prevent the lung inflammation and paraquat-induced alveolar damage. BMC Res Notes. 2019;12(1):584.

19. Oberkersch R, Attorresi Al, Calabrese GC. Low-molecular-weight heparin inhibition in classical complement activation pathway during pregnancy. Thromb Res. 2010;125(5):e240-5.

20. Girardi G, Redecha P, Salmon JE. Heparin prevents antiphospholipid antibody-induced fetal loss by inhibiting complement activation. Nat Med. 2004;10(11):1222-6.

21. Robinson S, Zincuk A, Strøm T, Larsen TB, Rasmussen B, Toft P. Enoxaparin, effective dosage for intensive care patients: double-blinded, randomised clinical trial. Crit Care. 2010;14(2):R41.

22. Coombe DR, Stevenson SM, Kinnear BF, Gandhi NS, Mancera RL, Osmond RIW, et al. Platelet endothelial cell adhesion molecule 1 (PECAM-1) and its interactions with glycosaminoglycans: 2. Biochemical analyses. Biochemistry. 2008;47(17):4863-75.

23. Gray E, Mulloy B, Barrowcliffe TW. Heparin and low-molecular-weight heparin. Thromb Haemost. 2008;99(5):807-18.

24. Wat JM, Audette MC, Kingdom JC. Molecular actions of heparin and their implications in preventing pre-eclampsia. J Thromb Haemost. 2018;16(8):1510-22. 
25. Sun S, Jiang Y, Wang R, Liu C, Liu X, Song N, et al. Treatment of paraquatinduced lung injury with an anti-C5a antibody: Potential clinical application. Crit Care Med. 2018;46(5):e419-25.

26. Sun S, Wang H, Zhao G, An Y, Guo Y, Du L, et al. Complement inhibition alleviates paraquat-induced acute lung injury. Am J Respir Cell Mol Biol. 2011;45(4):834-42.

27. Henry BL, Connell J, Liang A, Krishnasamy C, Desai UR. Interaction of antithrombin with sulfated, low molecular weight lignins: opportunities for potent, selective modulation of antithrombin function. J Biol Chem. 2009;284(31):20897-908.

28. Tsuchiya T, Yoshida T, Imaeda A, Kiho T, Ukai S. Detoxification of paraquat poisoning: effects of alkylsulfates and alkylsulfonates on paraquat poisoning in mice and rats. Biol Pharm Bull. 1995;18(4):523-8.

29. Perkins SJ, Fung KW, Khan S. Molecular interactions between complement factor $\mathrm{H}$ and its heparin and heparan sulfate ligands. Front Immunol. 2014;5:126
30. Boackle RJ, Caughman GB, Vesely J, Medgyesi G, Fudenberg HH. Potentiation of factor $\mathrm{H}$ by heparin: a rate-limiting mechanism for inhibition of the alternative complement pathway. Mol Immunol. 1983;20(11):1157-64

31. Riedl M, Fakhouri F, Le Quintrec M, Noone DG, Jungraithmayr TC, Fremeaux-Bacchi $V$, et al. Spectrum of complement-mediated thrombotic microangiopathies: pathogenetic insights identifying novel treatment approaches. Semin Thromb Hemost. 2014;40(4):444-64.

32. Mousavi S, Moradi M, Khorshidahmad T, Motamedi M. Anti-inflammatory effects of heparin and its derivatives: A systematic review. Adv Pharmacol Sci. 2015;2015:507151.

\section{Publisher's Note}

Springer Nature remains neutral with regard to jurisdictional claims in published maps and institutional affiliations.
Ready to submit your research? Choose BMC and benefit from:

- fast, convenient online submission

- thorough peer review by experienced researchers in your field

- rapid publication on acceptance

- support for research data, including large and complex data types

- gold Open Access which fosters wider collaboration and increased citations

- maximum visibility for your research: over $100 \mathrm{M}$ website views per year

At BMC, research is always in progress.

Learn more biomedcentral.com/submissions 